\title{
A Study of Clothing Purchasing Behavior By Gender with Respect to Fashion and Brand Awareness
}

\author{
Associate Prof . Emine Koca, PhD \\ Associate Prof. Fatma Koc, PhD \\ Gazi University, Faculty of Art and Design, \\ Department of Fashion Design, Ankara, Turkey
}

doi: 10.19044/esj.2016.v12n7p234 URL:http://dx.doi.org/10.19044/esj.2016.v12n7p234

\begin{abstract}
It has been suggested that male and female consumers demonstrate considerably different approaches in their decision-making and purchasing behavior when shopping for clothing for a variety of different reasons. For this reason, this study is centered on determining the degree to which gender affects the purchasing behavior of consumers buying fashion items and on determining what the differences between male and female consumer clothing purchasing behavior might be. The sample group for this study, which aims to identify the differences between male and female consumers from a gender perspective by examining their purchasing behavior with respect to fashion and brand awareness, was made up of 382 consumers chosen at random. The data used in this study were collected using a scaling tool made up of 29 questions devised by the researchers. The gathered data were then analyzed using the Social Sciences Statistics Packet (SPSS 17). As a result of this study it was determined that male and female consumers do have different perceptions and preferences with respect to fashion and brand awareness in their clothing purchasing behavior, that demographic characteristics were influential in purchasing clothing, and that women were more influenced by fashion while men were more influenced by brand name.
\end{abstract}

Keywords: Consumer, Clothing, Behaviour, Purchasing, Gender, Fashion, Brand name

\section{Introduction}

Clothing performs a multitude of functions in an individual's life far beyond being a basic necessity. Information and trends that are able to spread across the entire world not only drive consumers to purchase clothing, at the same time they encourage consumers to purchase even more clothing by offering them many more choices. This situation has led to a change in 
classic consumer culture and created consumer masses that prefer brand names and fashion, meaning products that possess social meaning in addition to just being functional, that provide status, arouse interest and that are innovative.

It has been suggested that these changes in consumer culture stimulated a dynamic renewal in the fields of consumerism and personal pleasure. This dynamism in consumer preferences is accepted worldwide as a part of an international cultural system while social values and lifestyles are driven by continual change (Hartley \& Montgomery, 2009).

The consumer patterns introduced by modern life create the need for a consumer field that can reflect the awareness of possessing a certain style as well as individual preferences and the characteristics unique to a specific group. While the individual consumes with the goal of being able to create a sense of identity and state who they want to be perceived as, the individual is able to achieve that goal only to the degree to which the clothes they use to create this identity are understood and interpreted by other individuals (Bocock, 2005, p. 24-27). The characteristic that fashion and brand name products have of being able to be understood and interpreted by individuals in society is the reason why they are so effective among all the factors that influence consumer behavior when purchasing clothing.

Globalization and increasing competition, and short product life cycles in fashion retailing, has affected consumer behavior. The factors that make consumers purchase particular products in the field of clothing, a field that nowadays has taken on multiple personal and social aspects that go beyond simple need, are many and various, and are influenced by diverse variables. When consumers make decisions about what clothing to buy they are influenced to a significant degree as much by the information they have been given by fashion, branding and marketing activities as they are by individual, psychological and social factors. In addition, such values as price, brand, quality, aesthetic value and usage characteristics present themselves as influencing qualities. The importance and degree of priority that these values hold for people constitute the differences in clothing purchasing behavior. In order to survive in fashion industry, consumer behavior is vital for manufacturers and retailers to develop and leverage core marketing capabilities.

According to Kotler (2001, p.25-28), the factors influencing a consumer's clothing purchase behavior can be put into the following groups: personal, psychological and cultural. The personal factors, which are among the most important factors determining consumers' clothing purchase behavior, are age, gender, profession, level of education, level of income and marital status (Muter, 2002, p. 23). Just as individuals are able to make different clothing choices depending on their psychological makeup and 
society's value judgments based on their gender, so it has also been determined by research that changes in social, physical, economic and psychological characteristics at different ages are able to influence people's preferences.

Grouped among the psychological factors, "personality characteristics do affect consumers' perceptions and purchasing behavior" (Stanton, Etzel, Walker, 1994, p.171). Personality, education, perception, impressionability and other exhibited attitudes, which all vary from one individual to another, may be listed as the psychological factors that can affect clothing purchasing behavior. Tek (1997) states that provided "there is strong correlation between certain personality types and products and brand names, personality could be an important factor in figuring out consumer behavior" (p.105).

Among those factors that make people buy a certain type of clothing or brand name, motivation and attitude are points that deserve special attention. For example, it is known that emotional motivation such as popularity and catching attention is influential in developing attitudes when deciding to buy clothing of a specific brand or fashion instead of buying clothing that is needed based on taking its functionality into consideration. "The three-dimensional attitude comprising the cognitive component that forms an individual's thoughts, knowledge and beliefs regarding a product or brand name, the emotional component that makes positive or negative evaluation and fuels the emotions accordingly, and the behavioral component defined as the behavioral inclination towards a product or brand name" (Wilkie, 1991, p.282) has close ties to purchasing behavior.

Another factor influential in consumers' purchasing behavior is the socio-cultural factor, which includes family, group, social class, peers and cultural makeup. It can be easily observed in everyday life that the culture and values encompassing all the factors giving direction to individuals' thoughts, behavior and attitudes do affect consumers' awareness of fashion and brand names, and that similarly individuals from different social classes possess different opinions with respect to fashion and brand name products in their clothing purchasing behavior.

While they may be treated under separate headings, when it is taken into consideration that the influence of personal factors is overpowering in individuals' purchasing behavior, it can be seen that the decision-making and purchasing behavior of male and female consumers can change depending on a variety of reasons having different dynamics. It is particularly known that consumers can and do exhibit different approaches with respect to fashion and brand names, which are able to influence the masses for a short time. 
One of the fundamental tenets of marketing is that brand images are an important determinant of buying behaviour. Brand image can be understood as the associations external target groups have in their minds about brands. These associations can be further divided into those concerning the functional attributes of a brand and those concerning the symbolic attributes of a brand. Due to the importance of brand images for the behaviour of various target groups, considerable attention has been paid to factors that possibly influence brand images (Burmann, Schaefer, Maloney,2008, p.157). Consumers who found value from a brand and treated it as an important thing to themselves, will more likely to develop good attitudes towards the brand. For this reason, this study aims to determine the degree to which gender difference influences behavior in purchasing fashion or brand name products and to identify what the differences are between male and female consumer clothing purchasing behavior.

Many researchers argue that while increasing globalization increases partnerships between countries it also reduces the homogeneous quality of consumer behavior within countries (Cleveland \& Laroche, 2007). In recent times, consumers have gained access to new and powerful tools. these consumer tools refer to new communication technologies such as the internet, mobile telephony and peer-to-peer connectivity. These are also critical consumer tools. Brands are familiar for many customers. Because brand values are used as tangible brand management tools to be shared with customers by brand-based organisations and brand managers (Harris, 2007). Cultural values, consumer preferences and the increases in the trend toward buying fashion and brand name products are inarguably the most critical topic faced by today's production and marketing managers. Many clothing manufacturing firms are trying to speed up their efforts to become brand names, to form bridges spanning differences between cultures in order to arouse interest in fashion products, and to create cultural harmony between various consumer groups. The differences in consumer purchasing behavior patterns at the same time determine the diversity and nature of clothing products. The consumer market for fashion apparel has become more diverse through fashion brands, store brands, personalization, advertising and ethnicity in the global marketplace. If manufacturers and retailers of fashion apparel can identify target consumers' preferences, they may be better able to attract and maintain their target consumer group (Rajagopal, 2011). According to Solomon (2002), knowledge of consumer behaviour directly affects marketing strategy. Firms can satisfy those needs only to the extent that they understand their customers. For this reason, marketing strategies must incorporate knowledge of consumer behaviour into every facet of a strategic marketing plan. Therefore, this study of clothing purchasing behavior is important for the sector. 


\section{Method and Sampling}

In order to reach the goal in this study, which was to identify the differences between male and female customers' clothing purchasing behavior with respect to fashion and brand name awareness, the following questions were asked:

1.Do the reasons given by the sample group for purchasing clothing differ according to gender?

2.Are the factors that influence the sample group's clothing purchasing behavior differ according to gender?

3.Is there any relationship between the way the sample group regards fashion and brand names and its behavior when purchasing clothing?

The data used in this study, the sample group for which was made up of 382 consumers - 86 women and 196 men - living in Ankara and chosen at random, were collected using a scaling tool comprised of 29 questions devised by the researchers. The collected data were analyzed using Social Sciences Statistics Packet (SPSS 17), a Chi-Square test was applied to determine the statistical relationship between gender and the reasons for buying clothes, the factors influencing purchasing behavior, plus regard and behavior concerning fashion and brand names. The results were interpreted as having a level of significance measuring $\mathrm{p}<0.05$.

The genders, ages and levels of education of the consumers in the study are given in Table 1.

Table 1 Distribution of Gender, Age and Level of Education Within Sample Group

\begin{tabular}{|c|c|c|c|c|c|c|c|c|c|c|c|c|}
\hline \multirow{3}{*}{ Gender } & \multicolumn{10}{|c|}{ Age } & \multirow{2}{*}{\multicolumn{2}{|c|}{ Total }} \\
\hline & \multicolumn{2}{|c|}{$21-25$} & \multicolumn{2}{|c|}{$26-30$} & \multicolumn{2}{|c|}{$31-35$} & \multicolumn{2}{|c|}{$36-40$} & \multicolumn{2}{|c|}{41 ve üzeri } & & \\
\hline & $\mathbf{F}$ & $\%$ & f & $\%$ & f & $\%$ & f & $\%$ & f & $\%$ & f & $\%$ \\
\hline Women & 136 & 73,1 & 14 & 7,5 & 21 & 11,3 & 9 & 4,8 & 6 & 3,2 & 186 & 100 \\
\hline Men & 107 & 54,6 & 22 & 11,2 & 14 & 7,1 & 17 & 8,7 & 36 & 18,4 & 196 & 100 \\
\hline \multirow[t]{3}{*}{ Total } & 243 & 63,6 & 36 & 9,4 & 35 & 9,2 & 26 & 6,8 & 42 & 11 & 382 & 100 \\
\hline & \multicolumn{10}{|c|}{ Education } & & \\
\hline & \multicolumn{2}{|c|}{$\begin{array}{c}\text { Primary } \\
\text { school }\end{array}$} & \multicolumn{2}{|c|}{$\begin{array}{l}\text { Middle } \\
\text { school }\end{array}$} & \multicolumn{2}{|c|}{$\begin{array}{c}\text { High } \\
\text { school }\end{array}$} & \multicolumn{2}{|c|}{$\begin{array}{l}\text { Graduate } \\
\text { (2years) }\end{array}$} & \multicolumn{2}{|c|}{ Graduate } & & \\
\hline Women & 8 & 4,3 & 1 & ,5 & 22 & 11,8 & 4 & 2,2 & 151 & 81,2 & 186 & 100 \\
\hline Men & 6 & 3,1 & 26 & 13,3 & 18 & 9,2 & 16 & 8,2 & 130 & 66,3 & 196 & 100 \\
\hline Total & 14 & 3,7 & 27 & 7,1 & 40 & 10,5 & 20 & 5,2 & 281 & 73,6 & 382 & 100 \\
\hline
\end{tabular}

When Table 1 is examined it can be seen that the age distribution within the sample group was 48.7 percent women to 51.3 percent men, that the highest concentration for age was in the 21-25 age bracket with 63.6 percent and that 73.6 percent possessed a bachelor's level degree.

\section{Findings and Interpretation}

Although people's behavior and attitudes are influenced to a significant degree by social factors, differences can also be due to the influence of personality traits, perception and prior experience. Therefore, 
people's demographic qualities play an important role in the variables for behavior and attitude, and these differences can be seen clearly in clothing purchasing behavior. Many studies showing that men and women differ in their purchasing behavior also tell us that gender creates differences in the reasons why people buy clothing. Table 2 shows the reasons by gender why the consumers in the study purchase clothes.

Table 2 Reasons by Gender for Purchasing Clothing

\begin{tabular}{|c|c|c|c|c|c|c|c|c|c|c|c|c|c|c|c|c|}
\hline \multirow{3}{*}{ Gender } & \multicolumn{6}{|c|}{ Feel a need } & \multicolumn{7}{|c|}{$\begin{array}{l}\text { Being different from those around } \\
\text { them }\end{array}$} & \multirow[b]{3}{*}{ df. ? } & & \\
\hline & \multicolumn{2}{|c|}{ Never } & \multicolumn{2}{|c|}{ Sometimes } & \multicolumn{2}{|c|}{$\begin{array}{l}\text { Every } \\
\text { time }\end{array}$} & \multirow{2}{*}{$\begin{array}{c}\text { p } \\
\text { df: } 2\end{array}$} & \multicolumn{2}{|c|}{ Never } & \multicolumn{2}{|c|}{ Sometimes } & \multicolumn{2}{|c|}{$\begin{array}{l}\text { Every } \\
\text { time }\end{array}$} & & \multicolumn{2}{|c|}{ Total } \\
\hline & f & $\%$ & f & $\%$ & f & $\%$ & & f & $\%$ & f & $\%$ & f & $\%$ & & f & $\%$ \\
\hline Women & 8 & 4,3 & 22 & 11,8 & 156 & 83,9 & \multirow{3}{*}{, $000^{*}$} & 70 & 37,6 & 74 & 39,8 & 42 & 22,6 & \multirow{3}{*}{,163 } & 186 & \multirow{3}{*}{100} \\
\hline Men & 22 & 11,2 & 48 & 24,5 & 126 & 64,3 & & 68 & 34,7 & 67 & 34,2 & 61 & 31,1 & & 196 & \\
\hline \multirow[t]{2}{*}{ Total } & 30 & 7,9 & 70 & 18,3 & 156 & 83,9 & & 138 & 36,1 & 141 & 36,9 & 103 & 27 & & 382 & \\
\hline & \multicolumn{6}{|c|}{$\begin{array}{c}\text { As a requirement of the working } \\
\text { environment }\end{array}$} & \multicolumn{7}{|c|}{ Conforming with friends } & & & \\
\hline Women & 62 & 33,3 & 62 & 33,3 & 62 & 33,3 & \multirow{3}{*}{, $021^{*}$} & 100 & 53,8 & 54 & 29 & 32 & 17,2 & \multirow{3}{*}{, $000^{*}$} & 186 & \multirow{3}{*}{100} \\
\hline Men & 42 & 21,4 & 86 & 43,9 & 68 & 34,7 & & 67 & 34,2 & 66 & 33,7 & 63 & 32,1 & & 196 & \\
\hline \multirow[t]{2}{*}{ Total } & 104 & 27,2 & 148 & 38,7 & 130 & 34 & & 167 & 43,7 & 120 & 31,4 & 95 & 24,9 & & 382 & \\
\hline & \multicolumn{6}{|c|}{ In order to lift their spirits } & \multicolumn{7}{|c|}{ Family/spouse's desire for difference } & \multirow{4}{*}{, $000^{*}$} & & \multirow{4}{*}{100} \\
\hline Women & 33 & 17,7 & 108 & 58,1 & 45 & 24,2 & \multirow{3}{*}{, $000^{*}$} & 128 & 68,8 & 37 & 19,9 & 21 & 11,3 & & 186 & \\
\hline Men & 67 & 34,2 & 77 & 39,3 & 52 & 26,5 & & 74 & 37,8 & 68 & 34,7 & 54 & 27,6 & & 196 & \\
\hline \multirow[t]{2}{*}{ Total } & 100 & 26,2 & 185 & 48,4 & 97 & 25,4 & & 202 & 27,5 & 105 & 27,5 & 75 & 19,6 & & 382 & \\
\hline & \multicolumn{6}{|c|}{ In order to conform to fashion } & \multicolumn{7}{|c|}{ Purchasing clothing desirable } & \multirow{4}{*}{, $013^{*}$} & & \multirow{4}{*}{100} \\
\hline Women & 68 & 36,6 & 71 & 38,2 & 47 & 25,3 & & 29 & 15,6 & 74 & 39,8 & 83 & 44,6 & & 186 & \\
\hline Men & 56 & 28,6 & 88 & 44,9 & 52 & 26,5 & ,226 & 23 & 11,7 & 56 & 28,6 & 117 & 59,7 & & 196 & \\
\hline Total & 124 & 32,5 & 159 & 41,6 & 99 & 25,9 & & 52 & 13,6 & 130 & 34 & 200 & 52,4 & & 382 & \\
\hline
\end{tabular}

According to Table 2, 83.9 percent of the sample group, being 83.9 percent of women and 64.3 percent of men, are seen to buy clothing "every time" they feel a need. 33.3 percent of the women stated they "always" bought clothing as a requirement of the working environment, while 34.7 percent of men answered "always" and a statistically significant 43.9 percent replied, "sometimes." This can be interpreted as men believing that the manner of dress is important when adapting to the working environment. Teber's (2004) definition: "The quantity and quality of our actions are conditioned by the quantity and quality of the socio-economic formations of the society we live in" ( p.30) supports this interpretation.

When the total for the replies of "sometimes" (58.1 percent) and "always" (24.2 percent) given by women consumers are taking into account, it can be seen that more women than men buy clothing "in order to lift their spirits." Conversely, when the total for the replies of "sometimes" (44.9 percent) and "always" (26.5 percent) given by male consumers are taken into account it can be seen that men buy clothing "in order to conform to fashion" far more than women do. Given the widespread notion that it is in women's nature to want to follow fashion, the results in Table 2 are remarkable. 
That more male consumers than female answered "always" to the choices of "being different from those around them" (31.1 percent), conforming with friends (32.1 percent) and "family/spouse's desire for difference (27.6 percent) not only makes one think that socio-cultural factors are more active among men's reasons for purchasing clothing, they also match Kotler's (1984) opinion that “a person's needs and actions are largely determined by the group they belong to or wish to belong to” (p.117).

Even though women were seen to purchase clothing they liked more often than men when the figures for "always" 44.6 percent and "sometimes" 39.8 percent were combined, the fact that 59.7 percent of men replied "always" for purchasing clothing they liked may be interpreted as their being more decisive in this area. In the Chi-Square test results in Table to a statistically significant $(p<0.05)$ relationship is found among the reasons for buying clothes, other than the options of "following fashion" and "standing out," given by the sample group by gender.

According to Kotler (2001) "the factors that influence a consumer's purchasing behavior can grouped as follows: personal, psychological and social-cultural” (p.25-28). In the sources of reference listed below age, gender, profession, education, marital status and level of income are seen as personal factors, learning, impressionability, perception and attitudes are seen as psychological factors while culture, social class, family and group are seen as socio-cultural factors. This being so, in accordance with the goal of this study, the factors influencing consumers' purchasing behavior by gender are presented in Table 3.

Table 3 Factors Influencing Purchasing Behavior by Gender

\begin{tabular}{|c|c|c|c|c|c|c|c|c|c|c|c|c|c|c|c|c|}
\hline \multirow{3}{*}{ Gender } & \multicolumn{6}{|c|}{ Fashion trends } & \multicolumn{7}{|c|}{ Family and close circle } & \multirow[b]{2}{*}{$p$} & & \\
\hline & \multicolumn{2}{|c|}{ Never } & \multicolumn{2}{|c|}{ Sometimes } & \multicolumn{2}{|c|}{$\begin{array}{c}\text { Every } \\
\text { time }\end{array}$} & \multirow{2}{*}{$\begin{array}{c}\text { p } \\
\text { df: } \\
2\end{array}$} & \multicolumn{2}{|c|}{ Never } & \multicolumn{2}{|c|}{ Sometimes } & \multicolumn{2}{|c|}{$\begin{array}{c}\text { Every } \\
\text { time }\end{array}$} & & \multicolumn{2}{|c|}{ Total } \\
\hline & $\mathbf{f}$ & $\%$ & f & $\%$ & f & $\%$ & & f & $\%$ & f & $\%$ & f & $\%$ & df: 2 & f & $\%$ \\
\hline Women & 32 & 17,2 & 84 & 45,2 & 70 & 37,6 & \multirow{3}{*}{,652 } & 16 & 8,6 & 76 & 40,9 & 94 & 50,5 & \multirow{3}{*}{, $000^{*}$} & 186 & \multirow{3}{*}{100} \\
\hline Men & 41 & 20,9 & 85 & 43,4 & 70 & 35,7 & & 49 & 25 & 66 & 33,7 & 81 & 41,3 & & 196 & \\
\hline Total & 73 & 19,1 & 169 & 44,2 & 140 & 36,6 & & 65 & 17 & 142 & 37,2 & 175 & 45,8 & & 382 & \\
\hline & \multicolumn{6}{|c|}{ Favorite brands } & \multicolumn{7}{|c|}{ Cultural values } & & & \multirow{4}{*}{100} \\
\hline Women & 38 & 20,4 & 83 & 44,6 & 65 & 34,9 & \multirow{3}{*}{,555 } & 9 & 4,8 & 54 & 29 & 123 & 66,1 & \multirow{3}{*}{, $000^{*}$} & 186 & \\
\hline Men & 32 & 16,3 & 89 & 45,4 & 75 & 38,3 & & 38 & 19,4 & 69 & 35,2 & 89 & 45,4 & & 196 & \\
\hline Total & 70 & 18,3 & 172 & 45 & 140 & 36,6 & & 47 & 12,3 & 123 & 32,2 & 212 & 55,5 & & 382 & \\
\hline & \multicolumn{6}{|c|}{ Economic situation } & \multicolumn{7}{|c|}{ Social status } & \multirow{4}{*}{,080 } & & \multirow{4}{*}{100} \\
\hline Women & 4 & 2,2 & 28 & 15,1 & 154 & 82,8 & \multirow{3}{*}{, 000} & 21 & 11,3 & 48 & 25,8 & 117 & 62,9 & & 186 & \\
\hline Men & 26 & 13,3 & 74 & 37,8 & 96 & 49 & & 30 & 15,3 & 65 & 33,2 & 101 & 51,5 & & 196 & \\
\hline Total & 30 & 7,9 & 102 & 26,7 & 250 & 65,4 & & 51 & 13,4 & 113 & 29,6 & 218 & 57,1 & & 382 & \\
\hline & \multicolumn{6}{|c|}{ Quality } & \multicolumn{7}{|c|}{ Psychological situation } & \multirow{4}{*}{, $000^{*}$} & & \\
\hline Women & 7 & 3,8 & 36 & 19,4 & 143 & 76,9 & \multirow{3}{*}{,000 } & 21 & 11,3 & 72 & 38,7 & 93 & 50 & & 186 & \multirow{3}{*}{100} \\
\hline Men & 23 & 11,7 & 78 & 39,8 & 95 & 48,5 & & 58 & 29,6 & 80 & 40,8 & 58 & 29,6 & & 196 & \\
\hline Total & 30 & 7,9 & 114 & 29,8 & 238 & 62,3 & & 79 & 20,7 & 152 & 39,8 & 151 & 39,5 & & 382 & \\
\hline
\end{tabular}


When Table 3 is examined, it can be seen that 65.4 percent of the sample group is influenced by the personal factor "economic situation" and that 82.8 percent of women are concentrated on the "always" choice. The "quality" factor ranks second with 62.3 percent with women (76.9 percent) seen as being influenced by this more than men (48.5 percent). Social status ranks third among the factors influencing sample group's purchasing behavior with 75.1 percent. Here, too, the proportion of women (62.9 percent) is higher than for men (51.5 percent). These are followed in order by cultural values, family and close circle then psychological situation. These factors too influence women to a higher degree than men.

Products and brand names are all status symbols for the individual and people prefer products and services that reflect their role and status in society (Kotler, 1984, 167). When Table 3 is studies in this regard, it can be seen that both factors "always" influence the purchasing behavior of 36.6 percent of the sample group and that this proportion is important when the ratios for "sometimes" are taken into account. Keller and Richey (2006) argue that "a product brand personality that typically relates to consumers and user imagery for a specific product brand” ( p.74).

Brand personality has been defined as the human characteristics or traits that can be attributed to a brand. The fact that there is a higher concentration of women in the fashion factor and a higher concentration of men in the brand name factor is thought of as the gender factor's distinct difference.

The Chi-Square test results in Table 3 show a statistically significant $(p<0.05)$ relationship between all the factors influencing the sample group's clothing purchasing behavior by gender apart from the fashion, brand name and social status factors.

In conclusion just as the factors influencing the sample group's clothing purchasing behavior can be listed in order as personal, social and psychological factors, it can be said that women are more influenced by these factors than men are.

Consumers' beliefs and attitudes have a marked effect on their purchasing behavior when it comes to choosing types of clothing and brand names. Attitude is a person's evaluation of, or feelings or inclination towards objects and ideas, and can be positive or negative. Belief covers knowledge, points of view and opinions (Durukan, 2006, p.38). Therefore, consumers' opinions about fashion and brand names, which appear to be an important factor when choosing clothing, are able to affect their attitudes and have an impact on their purchasing behavior. The findings concerning the sample group's opinions on fashion and brand names by gender are presented in Table 4. 
Table 4 Opinions by Gender About Fashion and Brand Name Clothing

\begin{tabular}{cc}
\hline FASHION & BRAND \\
\hline $\begin{array}{c}\text { Closely following fashion makes a } \\
\text { person feel good }\end{array}$ & $\begin{array}{c}\text { Brand name products are better } \\
\text { quality }\end{array}$ \\
\hline
\end{tabular}

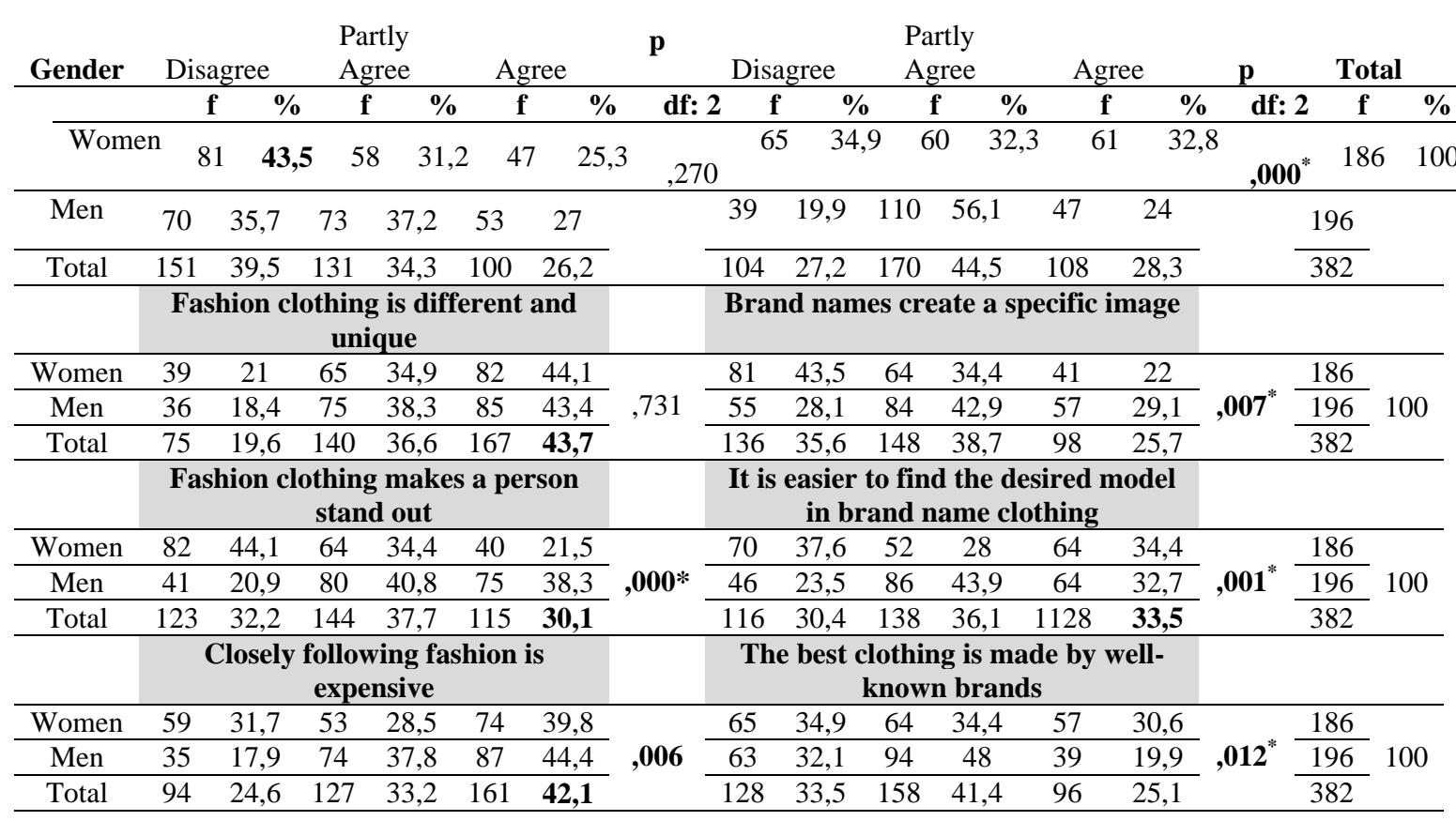

When the opinions about fashion in Table 4 are examined it can be seen that 43.5 percent of women and 35.7 percent of men do not agree with the opinion that "closely following fashion makes a person feel good" yet it can be said that the proportion of people who said "sometimes" is worthy of note. It can also be seen that 39.8 percent of women and 44.4 percent of men believe that "closely following fashion is expensive."

While 44.1 percent of women and 43.4 percent of men agreed with the opinion that "Fashion clothing is different and unique," 44.1 percent of women did not agree with the opinion that "fashion clothing makes a person stand out" but 38.3 percent of men did agree with it. Given these results it may be said that a significant proportion of the sample group was concentrated on the opinion that following fashion was expensive and that fashion clothing was different and unique, and that men more than women espoused the opinion that fashion clothing made a person stand out. The Chi-Square test results showed a statistically significant relationship between gender and the opinions "Closely following fashion is expensive" $(p=.006)$ and "Fashion clothing makes a person stand out" $(p=.000)$.

When the sample group's opinions concerning brand names are examined it can be seen that 32.8 percent of women agree with the opinion 
that brand name products are better quality and that 32,3 percent partly agree with this opinion while 24 percent of men agree with it and 56.1 percent partly agree with it. When the "sometimes" option is taken into account it can be said that men with 80.1 percent agree with the opinion "brand names are better quality" more than women with 70.1 percent.

While 29.1 percent of men agreed with the opinion that "brand names create a specific image" 42.9 percent of women partly agreed with this. This is supported by the idea that "Consumers treat products and brand names according to the image they have created and they purchase the image not the product" (Altunışık, 2004, p. 45). Given that 43.5 percent of women did not agree with this opinion and that similar results were observed for the opinion "the best clothing is made by well-known brands" may be interpreted as men having a more positive approach to brand name clothing than women. Given that a significant proportion of male consumers feel the need to purchase clothing because of the working environment (Table 2) it can be said that the opinion expressed by Rio and colleagues (2001) saying, "Consumers want to possess a specific brand in order to belong to a group and to possess a good reputation within that group" (p.412) supports this interpretation.

Some 34.4 percent of women and 32.7 percent of men stated they agreed with the opinion that "It is easier to find the desired model in brand name clothing." If the proportion of those who answered "sometimes" is taken into account it can be said that the previous interpretation concerning men's feelings for brand name clothing may still be valid. The Chi-Square test results in Table 4 show a statistically significant $(p<0.05)$ relationship between gender and all opinions about brand names.

Table 5 Sample Group's Purchasing Behavior by Opinion of Fashion Clothing

\begin{tabular}{|c|c|c|c|c|c|c|c|c|c|c|}
\hline \multicolumn{11}{|c|}{ FASHION } \\
\hline \multicolumn{11}{|c|}{ Closely following fashion makes a person feel good } \\
\hline \multirow{2}{*}{\multicolumn{2}{|c|}{$\begin{array}{l}\text { I am one of those Who } \\
\text { are the first to } \\
\text { purchase the new } \\
\text { products presented by } \\
\text { fashion }\end{array}$}} & \multicolumn{2}{|c|}{ Disagree } & \multicolumn{2}{|c|}{$\begin{array}{l}\text { Partly } \\
\text { Agree }\end{array}$} & \multicolumn{2}{|c|}{ Agree } & \multicolumn{2}{|c|}{ Total } & \multirow[b]{2}{*}{$\mathbf{p}$} \\
\hline & & f & $\%$ & f & $\%$ & f & $\%$ & $\mathbf{f}$ & $\%$ & \\
\hline \multirow[t]{3}{*}{ Disagree } & Women & 56 & 57,1 & 27 & 27,6 & 15 & 15,3 & 98 & \multirow{9}{*}{100} & \multirow{3}{*}{,640 } \\
\hline & Men & 42 & 58,3 & 16 & 22,2 & 14 & 19,4 & 72 & & \\
\hline & Total & 98 & 57,6 & 43 & 25,3 & 29 & 17,1 & 170 & & \\
\hline Partly & Women & 12 & 26,7 & 23 & 51,1 & 10 & 22,2 & 45 & & \multirow{3}{*}{,866 } \\
\hline \multirow[t]{2}{*}{ Agree } & Men & 20 & 31,3 & 30 & 46,9 & 14 & 21,9 & 64 & & \\
\hline & Total & 32 & 29,4 & 53 & 48,6 & 24 & 22 & 109 & & \\
\hline \multirow[t]{3}{*}{ Agree } & Women & 13 & 30,2 & 8 & 18,6 & 22 & 51,2 & 43 & & \multirow{3}{*}{, $010^{*}$} \\
\hline & Men & 8 & 13,3 & 27 & 45 & 25 & 41,7 & 60 & & \\
\hline & Total & 21 & 20,4 & 35 & 34 & 47 & 45,6 & 103 & & \\
\hline
\end{tabular}




\begin{tabular}{|c|c|c|c|c|c|c|c|c|c|c|}
\hline \multirow[t]{3}{*}{ Disagree } & Women & 22 & 22,4 & 35 & 35,7 & 41 & 41,8 & 98 & \multirow{9}{*}{100} & \multirow[t]{3}{*}{ 112 } \\
\hline & Men & 8 & 11,1 & 34 & 47,2 & 30 & 41,7 & 72 & & \\
\hline & Total & 30 & 17,6 & 69 & 40,6 & 71 & 41,8 & 170 & & \\
\hline \multirow{3}{*}{$\begin{array}{l}\text { Partly } \\
\text { Agree }\end{array}$} & Women & 10 & 22,2 & 24 & 53,3 & 11 & 24,4 & 45 & & \multirow{3}{*}{ 355 } \\
\hline & Men & 12 & 18,8 & 28 & 43,8 & 24 & 37,5 & 64 & & \\
\hline & Total & 22 & 20,2 & 52 & 47,7 & 35 & 32,1 & 109 & & \\
\hline \multirow[t]{3}{*}{ Agree } & Women & 7 & 16,3 & 6 & 14 & 30 & 69,8 & 43 & & \multirow{3}{*}{ 182 } \\
\hline & Men & 16 & 26,7 & 13 & 21,7 & 31 & 51,7 & 60 & & \\
\hline & Total & 23 & 22,3 & 19 & 18,4 & 61 & 59,2 & 103 & & \\
\hline \multicolumn{11}{|c|}{ Fashion clothing makes a person stand out } \\
\hline \multirow[t]{3}{*}{ Disagree } & Women & 55 & 56,1 & 34 & 34,7 & 9 & 9,2 & 98 & \multirow{9}{*}{100} & \multirow{3}{*}{, $000^{*}$} \\
\hline & Men & 25 & 34,7 & 23 & 31,9 & 24 & 33,3 & 72 & & \\
\hline & Total & 80 & 47,1 & 57 & 33,5 & 33 & 19,4 & 170 & & \\
\hline \multirow{3}{*}{$\begin{array}{l}\text { Partly } \\
\text { Agree }\end{array}$} & Women & 21 & 46,7 & 15 & 33,3 & 9 & 20 & 45 & & \multirow{3}{*}{, $002^{*}$} \\
\hline & Men & 10 & 15,6 & 37 & 57,8 & 17 & 26,6 & 64 & & \\
\hline & Total & 31 & 28,4 & 52 & 47,7 & 26 & 23,9 & 109 & & \\
\hline \multirow[t]{3}{*}{ Agree } & Women & 6 & 14 & 15 & 34,9 & 22 & 51,2 & 43 & & \multirow{3}{*}{,781 } \\
\hline & Men & 6 & 10 & 20 & 33,3 & 34 & 56,7 & 60 & & \\
\hline & Total & 12 & 11,7 & 35 & 34 & 56 & 54,4 & 103 & & \\
\hline \multicolumn{11}{|c|}{$\begin{array}{l}\text { Closely following fashion is } \\
\text { expensive }\end{array}$} \\
\hline \multirow[t]{3}{*}{ Disagree } & Women & 26 & 26,5 & 31 & 31,6 & 41 & 41,8 & 98 & \multirow{9}{*}{100} & \multirow[t]{3}{*}{,506 } \\
\hline & Men & 17 & 23,6 & 29 & 40,3 & 26 & 36,1 & 72 & & \\
\hline & Total & 43 & 25,3 & 60 & 35,3 & 67 & 34,4 & 170 & & \\
\hline \multirow{3}{*}{$\begin{array}{l}\text { Partly } \\
\text { Agree }\end{array}$} & Women & 23 & 51,1 & 8 & 17,8 & 14 & 31,1 & 45 & & \multirow{6}{*}{,189 } \\
\hline & Men & 10 & 15,6 & 30 & 46,9 & 24 & 37,5 & 64 & & \\
\hline & Total & 33 & 30,3 & 38 & 34,9 & 38 & 34,9 & 109 & & \\
\hline \multirow[t]{3}{*}{ Agree } & Women & 10 & 23,3 & 14 & 32,6 & 19 & 44,2 & 43 & & \\
\hline & Men & 8 & 13,3 & 15 & 25 & 37 & 61,7 & 60 & & \\
\hline & Total & 18 & 17,5 & 29 & 28,2 & 56 & 54,4 & 103 & & \\
\hline
\end{tabular}

In Table 5 when the clothing purchasing behavior of the sample group given their opinions of fashion clothing is examined a statistically significant relationship $(p=.010)$ can be seen between those who agree with the opinion that "Closely following fashion makes a person feel good" and those "who are the first to purchase the new products presented by fashion." This makes for the conclusion that a person's opinions influence their purchasing behavior. The statistically significant relationship between those who "sometimes" are "the first to purchase new products presented by fashion" and those who think "fashion clothing makes a person stand out" $(p=.002)$ and those who think "closely following fashion is expensive" $(p=.000)$ may be interpreted in the same way. 
Table 6 Sample Group's Purchasing Behavior by Opinion of Brand Name Clothing

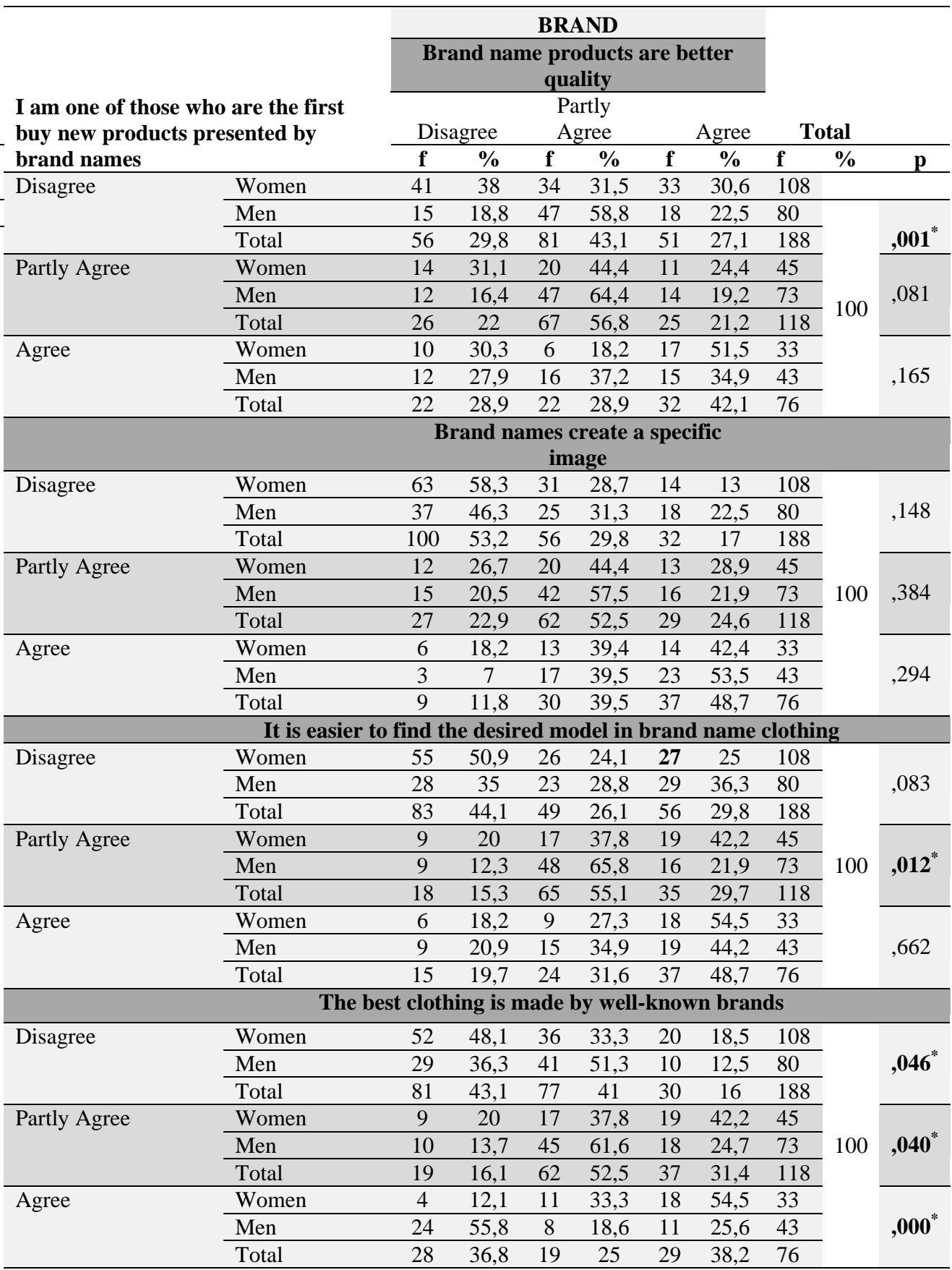

In Table 6 when the sample group's clothing purchasing behavior by opinion of brand name clothing is examined a statistically significant relationship $(p=.001)$ can be seen between those who disagree with the 
option "I am one of those who first buy new products presented by brand names" and those who believe "brand name products are better quality." A statistically significant relationship $(p=.012)$ was also found between those who answered that they "sometimes" are "among the first to purchase new products presented by brand names I like" and those who believe "The desired model is more easily found with brand name clothing." Similarly, a statistically significant relationship was found between the people "partly" agreeing with the opinion that "the best clothes are brand name clothes" $(p=.040)$ and those who agreed with this opinion $(p=.000)$.

The results in Table 5 and Table 6 may be treated as showing a significant parallel between consumers' opinions about fashion and brand name products and their clothing purchasing behavior.

\section{Conclusion and Suggestions}

It has been suggested that male and female consumers demonstrate considerably different approaches in their decision-making and purchasing behavior when shopping for clothing for a variety of different reasons. For this reason, this study is centered on determining the degree to which gender affects the purchasing behavior of consumers buying fashion items and on determining what the differences between male and female consumer clothing purchasing behavior might be. The following conclusions were reached in this study, which aimed to determine the differences in men and women consumers' clothing purchasing behavior with respect to the different genders' opinions about fashion and brand names:

- $\quad$ Even though an overwhelming majority of men and women say they purchase clothing when they feel the need to, proportionally more women than men say they purchase clothing "to bolster their spirits" but when the total proportions of men answering "sometimes" and "always" are taken into account it can be seen that men more than women purchase clothing "In order to conform to fashion."

- $\quad$ It can be seen that the first three factors influencing the sample group's clothing purchasing behavior are in order economic situation, quality and status followed in order by cultural values, family and close circle then psychological situation, and that women are more affected by these factors than men.

- $\quad$ It can be seen that a significant proportion of the sample group was concentrated around the opinion that closely following fashion is expensive and that fashion clothing is different and unique; it can also be seen that more men than women espouse the opinion that fashion clothing makes a person stand out.

- It can be seen that when purchasing clothing women are more influenced by fashion while men are more influenced by brand names. 
- It was concluded that there is a significant parallel between the sample group's opinions about fashion and brand name clothing and their clothing purchasing behavior.

It is thought that it would be beneficial for both corporate and consumer satisfaction if those businesses that manufacture clothing and that necessarily have to adapt to today's competitive climate and continually produce new products were to carry out research aimed at their own consumer masses when creating new products taking these kinds of studies into account.

\section{References:}

Altınışı, U. (2004). Marka Değeri Yaratmada Reklamın Rolü. İstanbul: Marketing Türkiye.

Bocock, R. (2005). Tüketim. 2th ed. Ankara: Dost Yayınları.

Burmann, C., Schaefer, K. \& Maloney, P. (2008). Industry image: Its impact on the brand image of potential employees. Journal of Brand Management, 15, 157-176.

Cleveland, M. \& Laroche, M. (2007). Acculturation to the global consumer culture: Scale development and research paradigm. Journal of Business Research, 60 (3), 249-259.

Hartley, J. \& Montgomery, L. (2009). Fashion as consumer entrepreneurship: Emergent risk culture, social network markets, and the launch of Vogue in China. Chinese Journal of Communication, 2(1), 61-76. Harris, P. (2007). We the people: The importance of employees in the process of building customer experience. Journal of Brand Management, 15, 102-114.

Durukan, F. N. (2006). Tüketici davranişlarinda öğrenmenin rolü ve bir uygulama. Yayınlanmamış yüksek lisans tezi. Dumlupınar Üniversitesi Sosyal Bilimler Enstitüsü, Kütahya- Türkiye. [The role of learning in consumer behavior and one application. Unpublished post-graduate thesis, Dumlupınar University, Social Sciences Institute- Turkey]

Keller, L. K. \& Richey, K. (2006). The importance of corporate brand personality traits to a successful 21st century business. Journal of Brand Management,14, 74-81.

Kotler, P. \& Armstrong. G. (2001). Principles Of Marketing, 9th ed. NewJersey: Prentice-Hall.

Kotler, P. (1984). Pazarlama Yönetimi. Translated: Y. Erdal. İstanbul:Beta Basım Yayım Dağıtım.

Muter, C. (2002). Bilinçaltı Reklamcılık (Biliçaltı Reklam Mesajlarının Tüketiciler Üzerindeki Etkileri). Ege Üniversitesi Sosyal Bilimler Enstitüsü Halkla İlişkiler ve Tanıtım Anabilim Dalı, Yayınlanmamış Yüksek Lisans Tezi. [Effects on Consumers of Subliminal Advertizing, Aegean University, 
Social Sciences Institute-İzmir, Public Relations and Promotions Branch, Unpublished Post-Graduate Thesis- Turkey]

Rajagopal. (2011).Consumer culture and purchase intentions toward fashion apparel in Mexico. Journal of Database Marketing \& Customer Strategy Management, 18, 286-307.

Rio, B. A., Vazquez, R. \& Iglesias,V. (2001). The Effects of Brand Associations on Consumer Response. Journal of Consumer Marketing, 18 (5), 410-425.

Solomon, M. (2002). Consumer Behavior: Buying, Having. And Being. 5th ed. New Jersey: Prentice Hall. Upper Saddle River.

Stanton,W, J., Etzel, M. J. \& Walker, B. J. (1994). Fundamentals of Marketing. New York: Mc Graw- Hill Comp.

Teber, S. (2004). Davranışlarımızın Kökeni. İstanbul: Say Yayınları.

Tek, Ö. B. (1997). Pazarlama Illkeleri, 8th ed. İstanbul: Beta Yayınları.

Wilkie, W. L. (1991). Consumer Behavior, 3th ed. New York.: John Wiely and Sons Inc. 